\title{
Implementing Student Tolerance and Patriotism Through Learning History of National Movements
}

\author{
Muslim $^{1 *}$, Warto $^{2}$, Djono $^{3}$ \\ ${ }^{1}$ Master Program in Historical Education, Faculty of Teacher Training and \\ Education, Sebelas Maret University, Surakarta \\ ${ }^{2}$ Lecturer and Professor, Sebelas Maret University, Surakarta \\ ${ }^{3}$ Lecturer, Sebelas Maret University, Surakarta \\ Corresponding author: ${ }^{1^{*}}$ muslim_161194@yahoo.com, ${ }^{2}$ warto_fle@yahoo.com, \\ 3djono_sk@yahoo.com
}

\begin{abstract}
This study aims to obtain: (1) inculcating the values of tolerance and patriotism of students through learning the history of the national movement, (2) difficulties experienced by history teachers, and (3) efforts made by history teachers to overcome these difficulties. This study uses qualitative methods, with a single embedded case study strategy. This study was conducted at SMA Negeri 11 Yogyakarta. Data were collected through observation, in-depth interviews, and document study. The data analysis technique used the interactive model of Miles and Huberman's analysis. The results of the study show that: (1) Inculcating the values of tolerance and patriotism in students, namely through learning preparation, learning implementation, (using the discussion method, because in discussions it is easy to instill the values of tolerance and patriotism in students), and evaluation (2) The difficulty faced by history teachers is that they have little time to study, and currently online learning makes it difficult for teachers to socialize with students. (3) Efforts made by history teachers, in overcoming these difficulties, were to make themselves role models and motivators for their students. In the end, after the obstacles were overcome, the students' tolerance and patriotism values increased.
\end{abstract}

Keywords: planting, tolerance value, patriotism, history of the national movement 


\section{Introduction}

Indonesia is a nation that has a unique character, consisting of various religions, races, tribes, and languages which are divided into islands. This phenomenon is often referred to as plurality. Individual urban life, prioritizing competition, often create separate social problems, such as crime, prostitution, abortion, poverty, urbanization, unemployment, and other social problems. This, coupled with the global dynamics that enter Indonesia freely, can directly influence the nation's future generations. Indonesia is a country with various religions and cultures. However, Indonesia is considered as a country that upholds tolerance between religions. Intolerance is still a great concern in the country. The intolerance that occurs in Indonesia generally occurs due to differences in religion and belief. Many cases of intolerance occur in the name of religion. For example, the rejection of the Shia by the Islamic Community Forum in Central Java and the refusal to build a mosque in Manado in September 2016. ${ }^{1}$

This difference must be accepted, enjoyed, and grateful for its extraordinary gifts by forming an inclusive and tolerant civilization in all aspects of life. However, what is happening now is the growth of a priori attitudes of a group of people that lead to exclusivism, namely the attitude that views their beliefs, views, thoughts, and group principles as the most correct, whereas; the beliefs, views, thoughts, and principles of other groups are wrong, misguided, and must be shunned. ${ }^{2}$ Recently, the life of Indonesian people has been marked by rampant radicalism, excessive religious fanaticism, and intolerance everywhere. The differences of opinion with one another seem to be getting tapered because of the human ego and nature that thinks they are the most righteous and others are guilty. There was a decrease in the sense of unity in the Republic of Indonesia. This situation certainly cannot be allowed to drag on. There must be differences of opinion because in this world nothing is alike and is the same even though they are twins. ${ }^{3}$

In 2009, the Central Bureau of Statistics found 1,128 ethnic groups in Indonesia. The Central Bureau of Statistics (Bakosurtanal), in 2006 published 726 regional languages which are used as a means of communication in Indonesia.

1 Muawanah, "Pentingnya Pendidikan Untuk Tanamkan Sikap Toleran Di Masyarakat," Jurnal Vijacariya 5, no. 1 (2018): 57-70.

2 Muhammad Sahal, Akhmad Arif Musadad, and Muhammad Akhyar, "Tolerance in Multicultural Education: A Theoretical Concept," International Journal of Multicultural and Multireligious Understanding 5, no. 4 (2018): 115-22.

3 E. Handayani Tyas and Lamhot Naibaho, "Building A Culture Of Tolerance Since Early Childhood," International Journal of Research -GRANTHAALAYAH 8, no. 08 (2020): 244-49, https://doi.org/DOI: https://doi.org/10.29121/granthaalayah.v8.i8.2020.999. 
This diversity brings a high tolerance for each individual. For the sake of peace and sustainability of a country, tolerance will reduce the potential for conflict in Indonesia. 1,128 is not a small number if it is placed on 17 thousand islands in this country. This number exceeds the number of countries recognized in the world. With this condition, again, tolerance is no longer an appeal but is the key for Indonesia to maintain the stability of its country, but the current condition is not as it should be. Indonesia is often hit by conflicts in the region. The start of East Timor (East Timor) at the beginning of reform, followed by riots between ethnicities, religions, and races (SARA) in Lampung, Poso, Sampit, and Sampang. Then the emergence of Separatist movements such as GAM (Free Aceh Movement) or OPM (Free Papua Organization). Example cases like this are none other than proof that we as a great nation have experienced a decline in our identity and national unity. ${ }^{4}$

Tolerance is a form of mutual respect and does not impose one's own will. Humans who consider themselves to be superior to others, good, and it is true this tendency can instill an attitude of intolerance. This primordial attitude which considers that his culture is better than other cultures is the cause of the dispute. ${ }^{5}$ Meanwhile, patriotism is defined as the spirit or soul possessed by someone to sacrifice or be willing to sacrifice for the sake of the nation and state. ${ }^{6}$ Learn to live together, live with other people so that we avoid socio-religious difficulties. Through education, the process of sowing and disseminating ideas, values, a spirit of solidarity, a spirit of tolerance, and a commendable attitude, all of which will ultimately lead to an agreement that we are one brother and sister, although in many ways we remain different. ${ }^{7}$

History is valuable because it provides opportunities for students to get to know the past, besides that one important function of history is the dedication of past community experiences which can help to solve problems at times. Vanderburg said that through historical learning, which seeks to form behavioral

4 Wimmy Haliim, "Harmony and Tolerance as a Tengger Identity: Reflections for Indonesian Identity and Unity Degradation," International Journal of Social Sciences 1, no. 1 (2018): 1-8, https://doi.org/https://doi. org/10.31295/ijss.v1n1.1.

5 Noor MS Bakry, Pendidikan Pancasila (Yogyakarta: Pustaka Pelajar, 2010).

6 Ainun Muchlisatun Rati Sugiman, "Penanaman Nilai-Nilai Nasionalisme dan Patriotisme melalui Materi Sikap Semangat Kebangsaan dan Patriotisme Dalam Kehidupan Bermasyarakat, Berbangsa Dan Bernegara Pada Pembelajaran PKn di SMAN 1 Pundong," Academy Of Education Journal. Pendidikan Pancasila Dan Kewarganegaraan 8, No. 2 (2017): 175.

7 Julianti Sormin, E., B. K., Nadeak, and Naibaho, "Use of Construction Inquiry Learning Model to Improve the Interest of Learning Students Grade XI SMA Angkasa 2 in Colloid Materials. PEOPLE:," International Journal of Social Sciences 5, no. 2 (2019). 
models which can foster values of tolerance and cultural patriotism in creating forms of relationships that transcend temporal and spatial environments. ${ }^{8}$ From the background description above, the author feels it is important to study the cultivation of the values of tolerance and patriotism of students through learning the history of the national movement at SMA Negeri 11 Yogyakarta.

\section{Literature Review}

Several previous studies have been carried out that are relevant to this study:

Research carried out by Muhammad Sahal, Akhmad Arif Musadad, and Muhammad Akhyar in 2018 in the International Journal of Multicultural and Multireligious Understanding entitled Tolerance in Multicultural Education: A Theoretical Concept. In this study, it is explained that multicultural education is education that prioritizes basic skills for world citizens, it is important for all students, through all aspects of the education system such as knowledge, building attitudes, and skills that allow students to work for social justice. Moreover, multicultural education is one of the important aspects of learning in schools that are needed in the education system as an effort to internalize the value of tolerance for students.

Research conducted by Puspo Nugroho in 2018 in the journal Nadwa: Journal of Islamic Education entitled Internalization of Tolerance Values in Islamic Education. This study aims to obtain a process of internalizing the values of religious tolerance such as rahmah, tauhid, musawah in educational institutions.

Research conducted by E. Handayani Tyas and Lamhot Naibaho in 2020 entitled Building A Culture of Tolerance Since Early Childhood. This study discusses life in Indonesia in a pluralistic society, harmony between religious communities is necessary. It will be very dangerous if children grow and develop with selfishness, close themselves, feel the most righteous, and want to win alone. Such conditions will make it difficult for children to adjust properly when they are still adolescents and adults.

Research conducted by Kartika Siregar, Djono, Leo Agung, in 2018, entitled Cultural Analysis in Willem Iskandar Si Bulus-Bulus Si Rumbuk-Rumbuk's Literary Works, in the Historical Journal of Citra Lekha, Vol. 3, No. 2, 2018. This article aims to discuss the literary work of Si Bulus-Bulus Si Rumbuk-Rumbuk

8 Dadang Supardan, "History Learning on the Approach of Multicultural and Local, National,Global History Perspective for National Integration ( A Quasi-Experimental Study on Senior High School Student in Bandung City," Jurnal Internasional, 2009. 
written by Willem Iskandar using a cultural perspective. Willem Iskandar is a writer who has produced literary works to build a revolutionary spirit for the advancement of South Tapanuli. The literary work that he produces implies the diction of the spirit for change. The literary works he wrote describe a lot about the culture in South Tapanuli. Si Bulus-Bulus Si Rumbuk-Rumbuk is his most popular work. Many messages are written in his work. The cultural depiction contained in his work invites the people of South Tapanuli to be more enthusiastic about making local wisdom a cultural heritage that must be preserved. His work describes the geographical conditions and conditions in South Tapanuli. This work was a great asset to advance education in South Tapanuli at that time.

Research conducted by Edwin Mirza Chaerulsyah (2014) entitled Student Perceptions of the Exemplary National Heroes to Increase National Spirit, in the Indonesian Journal of History Education, Vol. 3 (1) year 2014. objectives (1) How history carries out fostering exemplary values of national heroes in history learning to increase the national spirit of SMA Negeri 4 Tegal City students, (2) How about history lessons in discussing the history of national movements and the proclamation of Indonesian independence and the struggle to defend Indonesia's independence in Class X, XI and XII of SMA Negeri 4 Tegal City, (3) How to do the perceptions of SMA Negeri 4 Tegal City students about the exemplary national heroes in history learning.

Research conducted by Muhammad Usman (2019), which is entitled Internalization of Tolerance Values in Learning Islamic Religious Education at SMA Negeri 1 Lhokseumawe, Aceh, Indonesia, in DAYAH: Journal of Islamic Education Vol. 2, No. 1, 2019. This study discusses first, the value of tolerance obtained by students includes brotherhood, cooperation, respect, freedom, mutual assistance, non-discrimination, and sharing. Second, the process of internalizing values is carried out in three ways, namely school customs, integration, and activities outside the subject matter. Third, the supporting factors for internalization are competence and quality teachers, access to fair facilities, student extracurricular activities that are active in collaboration between teachers, support from school principals, heterogeneous awareness, active alumni, increased interest, and state policies. Meanwhile, the inhibiting factors for internalization include the absence of a tolerance-based module, the absence of tolerance-based guidance, the increase in racism, religion, and other sensitive issues, and the massive intolerance of media coverage. The learning module and teacher training should be given tolerance which is determined to be useful for enforcing the 
process of internalizing the value of tolerance in schools and reducing the issue of intolerance that is widespread in the mass media.

The difference between previous research and the study carried out in this study examines and describes the cultivation of students' values of tolerance and patriotism through learning the history of the national movement. Based on the function and purpose of learning history, inculcating the value of tolerance and patriotism of students through learning the history of the national movement is expected to foster values of tolerance and patriotism for students in everyday life. From some of the relevant studies above, there are efforts to instill exemplary values from national figures, as well as through the values given by national figures. Likewise, this study aims to describe the efforts to instill the values of tolerance and patriotism of students through learning the history of the national movement, so that the values of tolerance and patriotism of students can be lived, understood, and manifested in students' daily lives.

\section{Research Methods}

This study uses qualitative research methods, which aim to get a clear picture of the situation and the emphasis is on the process and it's meaning. This research emphasizes the inculcation of students'values of tolerance and patriotism through learning the history of the national movement at SMA Negeri 11 Yogyakarta, resulting in words about preparation, implementation, evaluation, and difficulties faced by history teachers, as well as the efforts of history teachers in overcoming these difficulties. This research uses a single fixed case research strategy because it is only carried out on one target (one subject or one location), because the focus of the problem is on research that has been written before, indicating the research was carried out, so the case study research or case study strategy is more, in particular, it can be said of a single fixed case study. The first data source of this research is the results of observations and the results of interviews with the principal, history teacher, curriculum waka, waka public relations, which have been carried out in the field and then the results of this interview are recorded using a cellphone then written through written notes, for observations in research can only observe the learning. through WhatsApp social media, because when doing research the school applied online learning through WhatsApp, Google School, and Google Classroom social media to conduct discussions and questions and answer questions, so the learning process was not carried out in class. While the second data source in this research books, reputable journals, RPP (Learning 
Implementation Plan, Student Worksheet) in the form of individual papers and mind mapping group assignments and learning media in the form of PowerPoint slides of historical figures of the national movement. , and the documentation related to the theme of the research carried out was obtained from the internet, the library and documentation at the time of the research. The informants who were asked for their opinion were the History Teacher, Principal, Deputy for Public Relations, Deputy Curriculum, and one of the students at SMA Negeri 11 Yogyakarta The data were collected through observation, in-depth interviews, and document study The data analysis technique used the interactive model of Miles and Huberman's analysis The data validity in this study used triangulation to obtain valid data. The triangulation used in this research is source triangulation (data) and method triangulation. Triangulation of sources (data) in this study can be obtained from sources (humans) with different positions by conducting indepth interviews so that data or information from one source can be compared with data or information from other sources. For example, information about the inculcation of students' values of tolerance and patriotism through learning the history of the national movement at SMA Negeri 11 Yogyakarta in this study was obtained from the principal, history teacher, public relations assistant, curriculum waka, and one of the students of SMA Negeri 11 Yogyakarta. Triangulation of the method in this research was obtained by interviewing, document study and observation of learning carried out by teachers and students when the learning process research was carried out online, through WhatsApp social media, so that in the research, they could only observe the learning process be it discussion students and teachers answer only through WhatsApp social media, for power points and materials sent via Google Classroom and Google School.

\section{Result and Discussion}

\subsection{Learning Preparation}

Learning preparation is a description of some of the activities and actions were taken during the learning process. ${ }^{9}$ Majid revealed that preparation is the process of preparing subject matter, using teaching media, using teaching approaches and methods, and assessing the time allocation which is carried out at a certain time to achieve predetermined goals. Preparation includes a series

9 Numiek Sulistyo Hanum, "Keefetifan E-Learning Sebagai Media Pembelajaran (Studi Evaluasi Model Pembelajaran e-Learning SMK Telkom Sandhy Putra Purwokerto)," Jurnal Pendidikan Vokasi, 2013, https://doi.org/10.21831/jpv.v3i1.1584. 
of activities to determine general goals (goals) and specific goals (objectivity) of an organization or institution implementation of education, based on complete information support. ${ }^{10}$ According to Leo Agung and Sri Wahyuni several benefits can be learned from the preparation of learning preparation, namely: a) Through a thorough learning preparation process, chancy success will be avoided. b) Preparation of learning as a tool to solve problems. c) To utilize various sources appropriately. d) Preparation will be able to make learning take place systematically. ${ }^{11}$

The preparation stage is a process that is carried out so that the specified goals can be achieved. According to Emanuela Bintarti El, the preparation stage includes preparation of the syllabus as a guide in the preparation of a Learning Implementation Plan, a Learning Implementation Plan (hereinafter referred to as RPP) as a guide in teaching which includes media design, methods, materials, and learning evaluation. ${ }^{12}$

The preparation stage is the stage to see how readiness of teachers who teach history subjects to compile learning scenarios, compile materials, carry out learning, and conduct assessments. The history teacher at SMA Negeri 11 Yogyakarta has prepared good lesson preparation with one lesson plan for 2 meetings, the teacher has instilled the values of tolerance and patriotism of students that have been included in the lesson plans. At the time of this preparation, the history teacher made RPP programs during one semester of RPP development by instilling the values of tolerance and patriotism of students, for example, the values of morality in the form of courtesy, communicative values, values of enthusiasm, respect for friends and teachers, responsibility by completing the assigned tasks teachers, honestly, accept differences of opinion in group discussions with other friends.

\subsection{Implementation of Learning}

Education is an effort to prepare students for an environment that is experiencing increasingly rapid changes. Community change includes the values agreed upon by the community. Meanwhile, all values that have been agreed upon by the community are called culture. In this case, culture is said to be a

10 Annisa Fitri, "Perencanaan Pembelajaran Kurikulum 2013 Pendidikan Anak Usia Dini," Jurnal Ilmiah POTENSLA, 2017, https://doi.org/10.33369/jip.2.1.

${ }^{11}$ Leo Agung and Sri Wahyuni, Perencanaan Pembelajaran Sejarah (Yogyakarta: Ombak, 2013).

${ }^{12}$ HT Atmaja I Ilyasin, S Amin, "Persepsi Siswa Etnis Tionghoa Terhadap Pembelajaran Sejarah Pokok Bahasan Pergerakan Nasional Di SMA Kristen Wonosobo,” Indonesian Journal of History, 2019. 
concept that has high complexity. ${ }^{13}$ Meanwhile, Dimyati and Mudjiono said that science and technology are values that come from thoughts or logic, meanwhile, art is rooted in feeling or aesthetics. The socio-cultural values of society are rooted in the work of humans so that in receiving, disseminating, preserving, or releasing them humans always use reason. ${ }^{14}$ The implementation of history learning at SMA Negeri 11 Yogyakarta has been planned in the learning device.

This is following what was stated by Nana Sudjana that the implementation of learning is a process that is arranged in such a way as to take certain steps so that the implementation achieves the expected things. ${ }^{15}$ The implementation of internalized history learning with the values of tolerance and patriotism consists of three stages of activity, namely preliminary activities, core activities, and closing activities. History learning is carried out through social media WhatsApp, Google School, and Google Classroom. The history lessons taught are historical material of the national movement, this material is the right means of instilling the value of tolerance and patriotism in students at SMA Negeri 11 Yogyakarta because SMA Negeri 11 Yogyakarta is a school that was once the place where Budi Utomo's first congress was held on 1908, which is a symbol of national awakening. The learning process uses the discussion method because in discussions it is easy to instill the value of tolerance and patriotism in students, for example, students are trained to confidently speak in front of a crowd, students are trained how to respect the opinions of other friends, students practice how to communicate well by expressing their opinions and responding to other people's opinions, but because currently learning is online, the teacher instructs students to make individual papers and group mind mappings, then this task will be uploaded to the Google Classroom, even though the learning is online, the students' collaboration in completing their assignments is still maintained. Well. ${ }^{16}$

All existing facilities and infrastructure must be used, such as using LCD, WhatsApp, Google Classroom, to display power points, concept maps, and mind mapping or to screen films, videos, songs, history teachers in teaching the national movement material online because The school is currently implementing online learning, so in teaching the material on the history of the national movement, the teacher first makes a summary of the material, then makes a PowerPoint on

\footnotetext{
13 Robert S Zais, Curriculum: Principles and Foundations (New York: Crowell, 1976).

14 Dimyati \& Mudjiono, Belajar Dan Pembelajaran (Jakarta: Rineka Cipta., 2013).

15 Nana Sudjana, Dasar-Dasar Proses Belajar (Bandung: Sinar Baru, 2010).

16 Yuris Prudisia, "Wawancara Pribadi Dengan Guru Sejarah SMA Negeri 11 Yogyakarta” (Yogyakarta, 2020).
} 
the history of the national movement and the concept map, especially teaching material from historical figures of national movements such as the Budi Utomo organization, Indische Partij, PNI, NU, Muhammadiyah, RA Kartini, and so on, then the teacher ordered students to make individual paper assignments, make mind mapping group assignments, as well as concept maps for XI IPS 2 class students and IPS 1 class students from the history of national movement material, then the students' work was uploaded to Google Classroom. ${ }^{17}$

\subsection{Learning Evaluation}

Learning evaluation is an evaluation activity carried out in the learning process including planning, implementation, and the assessment process and its impact on students. This evaluation is carried out to correct deficiencies in learning and can be used as a basis for further learning processes. ${ }^{18}$ The evaluation model is useful in guiding management, data collection, and analysis. ${ }^{19}$ Learning evaluation is an indicator tool for assessing the achievement of predetermined goals and assessing the overall teaching implementation process. Evaluation is not just assessing an activity spontaneously and incidentally but is an activity to assess something in a planned, systematic and directed manner based on clear objectives. ${ }^{20}$

Evaluation and results of learning history to instill the value of tolerance and patriotism of students seeing various aspects of assessment. The history teacher at SMA Negeri 11 Yogyakarta has done well overall. According to Anas Sudijono said that evaluation of learning outcomes can be carried out well if in practice it adheres to three principles, namely the overall principle, the principle of sustainability, and the principle of objectivity. ${ }^{21}$ This means that the overall principle and continuity have been carried out properly by the history teacher. This is based on the that the aspects used as an assessment of learning outcomes are guided by cognitive, affective, and psychomotor aspects.

\footnotetext{
17 Prudisia.

18 Astin Lukum, "Evaluasi Program Pembelajaran IPA SMP Menggunakan Model Countenance Stake," Jurnal Penelitian Dan Evaluasi Pendidikan, 2015, https://doi.org/10.21831/pep.v19i1.4552.

19 Lukum.

20 Hanum, "Keefetifan E-Learning Sebagai Media Pembelajaran (Studi Evaluasi Model Pembelajaran eLearning SMK Telkom Sandhy Putra Purwokerto)."

21 Sudijono Anas, Pengantar Evaluasi Pendidikan. (Jakarta: PT. Grafindo Persada, 2007).
} 


\subsection{Difficulties Faced by History Teachers in Learning}

The difficulty encountered in learning the history of the national movement is the limited learning time, while the material on the history of the national movement is many so that in teaching the material on the history of the national movement cannot be explained completely, only important materials are taken which will be tested in daily tests. , MID, and UAS because if students are given too much subject matter, they can feel bored in learning, and because currently learning is online so that teachers cannot monitor what students do as it is when learning is done in class. ${ }^{22}$ The efforts made by history teachers in overcoming the difficulties that arise in instilling the value of tolerance and patriotism of students are to make themselves as role models for their students, and as motivators by commemorating national holidays such as national awakening day, youth oath, 17 August 1945, supernatural powers Pancasila, holds a mandatory agenda for visits to historical places.

\section{Conclusion}

History teaching preparation at SMA Negeri 11 Yogyakarta has been very well planned by the history teacher. This can be proven by the existence of learning tools that have been compiled and adapted to the 2013 curriculum. The implementation of learning has been planned in the learning tools, first, the teacher asks questions to students regarding the material being studied by students, the two teachers divide students into groups, because of the learning method. used is the discussion method, the three individual papers that are not presentations are required to give questions to the papers that appear or are presentations, and after the discussion is over the teacher gives five questions to students who do not present or are given a post-test. Evaluation in history learning, history teachers have used the principle of overall and continuous evaluation and have been carried out well by history teachers. The difficulty faced by history teachers is that they have little learning time, and nowadays online learning makes it difficult for teachers to socialize with students. The efforts made by history teachers to overcome these difficulties were to make themselves role models and motivators for their students.

$\overline{22}$ Prudisia, "Wawancara Pribadi Dengan Guru Sejarah SMA Negeri 11 Yogyakarta." 


\section{Acknowledgment}

Thanks to the key sources of this research, namely Mr. Rudy Rumanto, S. Pd., M. Pd, Yuris Prudisia, S.Pd, Ruswidaryanto, S. Pd, Sihana, S. Pd., M. Sc.

\section{Reference}

Agung, Leo, and Sri Wahyuni. Perencanaan Pembelajaran Sejarah. Yogyakarta: Ombak, 2013.

Anas, Sudijono. Pengantar Evaluasi Pendidikan. Jakarta: PT. Grafindo Persada, 2007.

Bakry, Noor MS. Pendidikan Pancasila. Yogyakarta: Pustaka Pelajar, 2010.

Dimyati \& Mudjiono. Belajar Dan Pembelajaran. Jakarta: Rineka Cipta., 2013.

Fitri, Annisa. "Perencanaan Pembelajaran Kurikulum 2013 Pendidikan Anak Usia Dini.” Jurnal Ilmiab POTENSIA, 2017. https://doi.org/10.33369/ jip.2.1.

Haliim, Wimmy. "Harmony and Tolerance as a Tengger Identity: Reflections for Indonesian Identity and Unity Degradation." International Journal of Social Sciences 1, no. 1 (2018): 1-8. https://doi.org/https://doi.org/10.31295/ijss. v1n1.1.

Hanum, Numiek Sulistyo. "Keefetifan E-Learning Sebagai Media Pembelajaran (Studi Evaluasi Model Pembelajaran e-Learning SMK Telkom Sandhy Putra Purwokerto)." Jurnal Pendidikan Vokasi, 2013. https://doi. org/10.21831/jpv.v3i1.1584.

I Ilyasin, S Amin, HT Atmaja. "Persepsi Siswa Etnis Tionghoa Terhadap Pembelajaran Sejarah Pokok Bahasan Pergerakan Nasional Di SMA Kristen Wonosobo." Indonesian Journal of History, 2019.

Lukum, Astin. "Evaluasi Program Pembelajaran IPA SMP Menggunakan Model Countenance Stake.” Jurnal Penelitian Dan Evaluasi Pendidikan, 2015. https://doi.org/10.21831/pep.v19i1.4552.

Muawanah. "Pentingnya Pendidikan Untuk Tanamkan Sikap Toleran Di Masyarakat." Jurnal Vijjacariya 5, no. 1 (2018): 57-70.

Nana Sudjana. Dasar-Dasar Proses Belajar. Bandung: Sinar Baru, 2010.

Prudisia, Yuris. "Wawancara Pribadi Dengan Guru Sejarah SMA Negeri 11 Yogyakarta.”Yogyakarta, 2020. 
Sahal, Muhammad, Akhmad Arif Musadad, and Muhammad Akhyar."Tolerance in Multicultural Education: A Theoretical Concept." International Journal of Multicultural and Multireligious Understanding 5, no. 4 (2018): 115-22.

Sormin, E., Julianti, B. K., Nadeak, and Naibaho. "Use of Construction Inquiry Learning Model to Improve the Interest of Learning Students Grade XI SMA Angkasa 2 in Colloid Materials. PEOPLE:" International Journal of Social Sciences 5, no. 2 (2019).

Sugiman, Ainun Muchlisatun Rati. "Penanaman Nilai-Nilai Nasionalisme dan Patriotisme melalui Materi Sikap Semangat Kebangsaan dan Patriotisme dalam Kehidupan Bermasyarakat, Berbangsa dan Bernegara pada Pembelajaran PKn di SMAN 1 Pundong." Academy Of Education Journal. Pendidikan Pancasila dan Kerwarganegaraan 8, no. 2 (2017): 175.

Supardan, Dadang. "History Learning on the Approach of Multicultural and Local, National,Global History Perspective for National Integration ( A Quasi-Experimental Study on Senior High School Student in Bandung City." Jurnal Internasional, 2009.

Tyas,E.Handayani, and Lamhot Naibaho. "Building A Culture OfTolerance Since Early Childhood." International Journal of Research-GRANTHAALAYAH 8, no. 08 (2020): 244-49. https://doi.org/DOI: https://doi.org/10.29121/ granthaalayah.v8.i8.2020.999.

Zais, Robert S. Curriculum: Principles and Foundations. New York: Crowell, 1976. 
